\title{
DEVELOPING CREDIT CARD MARKET FROM VIETNAMESE CONSUMERS' PERSPECTIVE
}

\author{
VUONG DUC HOANG QUAN \\ Ho Chi Minh City Institute for Development Studies - quanvuong.aca@ gmail.com
}

TRINH HOANG NAM

Banking University Ho Chi Minh City - thnamfb@gmail.com

(Received: November 16, 2016; Revised: March 16, 2017; Accepted: April 10, 2017)

\begin{abstract}
This study aims to identify the factors affecting the intention to use credit cards in Vietnam. Previous empirical studies on planned and actual behaviors showed that customers decide to own and use credit cards through their awareness of credit card, including perceived usefulness, perceived behavioral control and subjective norm. To collect the data, we use structured self-administered questionnaires from 426 respondents making payments through bank accounts. The findings shows that perceived usefulness, perceived behavioral control and subjective norm have positive impact on credit card's adoption among Vietnamese consumers. This study also supposes that customers from different demographics have different intention to use credit cards. Some recommendations are made to improve the effects of banks' policies on credit card application and use.
\end{abstract}

Keywords: Credit card; intention to use; TPB; TAM; SEM; Vietnam.

\section{Introduction}

Credit cards, a combination of payment cards and consumer lending instruments, are based on the application of information technology. Nowadays, credit cards are widely used around the world with six international brands including American Express (1958), Diners Club (1961), JCB (1961), Visa (1977), MasterCard (1979), and CUP (2002). In Vietnam, credit cards were first introduced by Bank for Foreign Trade of Vietnam (Vietcombank) and Asia Commercial Bank in the early of 1996. After that, technology infrastructure, technical equipment and human resources are continuously developed by Vietnamese banks to expand the credit card business system. As a result, by end of 2014, 37 of 51 Vietnamese banks have issued and acquired credit cards with large payment networks.

According to 2014 payment card market report, Vietnamese banks have issued more than 3 million credit cards out of the total of 80 million bank cards on the market (equivalent to $2.75 \%$ of all card types), an increase of 1.3 million (or $45 \%$ ) compared to end of 2013. Total value of credit card transactions in 2014 was about 2 billion US dollars, increasing 500 million US dollars (or $33 \%$ ) compared to 2013. However, this figure is still small compared to total value of payment card market (about 65 billion US dollars). Over the last five years, there has been a shift from paying by debit cards to by credit cards. However, the shift was not really prominent when contribution rate of credit cards to the bankcard market only changed from $1.9 \%$ (2010) to $3.1 \%$ (2014).

When deploying credit cards business system, Vietnamese banks have expected in the vast potential market of more than 54.8 million workers, of which about 33 million are at golden age (GSO, 2015), who love technology and tend to accept credit cards than other ages (Teoh et al., 2013).Vietnamese educational level has improved year after year. The proportion of people with high school or higher education degrees was $26.5 \%$ in 2014 compared to $20.8 \%$ in 2009 (GSO, 2015). They can easily 
understand and access to modern banking services including credit cards (Yayar and Karaca, 2012). Moreover, along with the steady and continuous growth of Vietnam's economy, the average personal income has raised twice over 5 years from 2009 to 2014 (GSO, 2015). This setting makes credit cards "an appropriate and efficient choice" (Hussin, 2013) for many people who desire a better and modern way of living. Vietnamese consumers are more likely to own and use credit cards. The problems are how to identify potential customers quickly, analyze their motives, set up suitable business policies to raise their awareness, and encourage them to sign up and use credit cards.

So far, the number of Vietnam's academic publications and research about credit cards and related issues is still limited. These studies are mainly investigated Vietnamese credit cardholders to assess quality of credit card services, identify customers' satisfaction with credit card services, or manage credit card delinquency. Then some recommendations are made to help increase sales and control overdue credit cards. However, to boost credit cards business, not only should banks focus on existing credit card users but they should also seek for potential customers, especially those like paying through bank accounts. For these customers, acceptance of credit cards depends mainly on their subjective awareness of credit cards. If the awareness is positive, they may be interested in the benefits brought by credit cards and wish to own and use credit cards as a means for their future payment. This view has not been mentioned in recent studies about credit cards in Vietnam.

This study aims to clarify factors affecting Vietnamese consumers' acceptance of credit cards in view of the fact that their actions are rationally based on their subjective awareness of credit cards. Consumers' awareness of credit cards includes perceived usefulness, perceived behavioral control and subjective norm as proposed by Ajzen and
Fishbein (1980), Ajzen (1991), Davis et al. (1989), and Venkatesh and Davis (2000). Based on the findings, some recommendations will be made to help improve Vietnamese customers' intention to use credit cards, thus encourage them to sign up and use credit cards to develop Vietnamese credit card market at the same level as that of other countries.

\section{Literature Review}

Based on Theory of Reasoned Action, TRA (Ajzen and Fishbein, 1980), Davis et al. (1989) first proposed the Technology Acceptance Model (TAM) to focus specifically on customers' adoption of computer innovation. In this extension of TRA, Davis et al. (ibid) hypothesized that consumers' beliefs in a computer innovation will impact their intention to adopt a new technology and then their actual use of the new technology. These beliefs include perceived ease of use of computer innovation and perceived usefulness of technology Davis et al. (ibid). However, intended behavior is regarded as a primary determinant of actual behavior (Ajzen and Fishbein, 1980). It reasonably represents for actual behavior (Chau and $\mathrm{Hu}, 2002$ ) and is selected to assess users' acceptance of technology instead of the actual behavior (Lu et al., 2003).

Ajzen (1991), in proposal of Theory of Planned Behavior (TPB), proved that sometimes customers are uncontrolled in their behaviors or their intention is affected by perceived behavioral control. Ajzen (1991) also stated that customers' adoption of technology is dominated by the TPB through factors such as attitude, subjective norm, and perceived behavioral control. And attitude is representative factor of perceived ease of use and perceived usefulness. However, Venkatesh and Davis (2000) considered that perceived usefulness cannot be replaced by attitude and perceived usefulness; and perceived ease of use directly affect intended behavior. Whereby, Venkatesh and Davis (2000) proposed new version of TAM, in 
which the adoption of technology is affected by subjective norm, perceived usefulness and perceived ease of use. Regarding perceived ease of use, Ajzen (2002) proposed that this factor is part of perceived behavioral control and can be replaced by perceived behavioral control. Thus, customers' subjective norm, perceived usefulness and perceived behavioral control will impact their intention to adopt a new technology.

Credit cards, also known as noncash or electronic payment instruments, are issued and managed by banks and used by customers in automatic teller machines, point of sales, or in the form of e-commerce business (Meier and Stormer, 2009). With the increasing development of e-commerce business, credit cards have importantly been regarded as a favorite and favorable tool for e-payment (Lee and Cata, 2005). Meanwhile, TAM and its versions (Davis et al., 1989; Venkatesh and Davis, 2000; Ajzen, 1991, 2002) have been widely used in studies about customers' intention to use e-commerce (Park et al., 2004; Hsinkung et al., 2011), e-payment (Lin and Nguyen, 2011; Teoh et al., 2013) and ebanking (Zhao et al., 2008; Payam and Hamid, 2012). Thus, TAM and its versions are suitable for studies about intention to use credit cards.

\section{Customers' perceived usefulness and} their intention to use credit cards

The perceived usefulness was proposed by Davis et al. (ibid) as the degree to which a person believes that using a particular system would enhance his or her job performance. Chan (1997), Alhassan and Yakubu (2007) supposed that convenience is the main driver in the decision of using credit cards. Consumers are very interested in grace period and low interest as the two most advantages of credit cards (Chan, 1997). Consumers used credit cards not only as a substitute for cash and checks (Hsu and Chiu, 2004; Luarn and Lin, 2005; Thomas et al., 2010) but also as a source of revolving credit (Sudhagar, 2012; Pudaruth et al., 2013). Consumers preferred credit cards due to the risk of carrying cash (Barker and Sekerkaya, 1992; Lee and Kwon, 2002; Norum, 2008 Sudhagar, 2012). Kaynak and Harcar (2001), Roberts and Jones (2001), Thomas et al. (2010) posited that ease access to cash was the key factor for the use of credit cards. Thus, the hypothesis related to the perceived usefulness may be introduced as follows:

H1: Perceived usefulness has a positive effect on intention to use credit card.

Customers' subjective norm and their intention to use credit cards

Ajzen (1991) considered subjective norm as the perceived social pressure to perform or not to perform the behavior, that is, subjective norm has a direct effect on intended behavior (Ajzen, ibid; Taylor and Todd, 1995). Although Davis et al. (ibid) eliminated subjective norm out of TAM because they failed to show its contribution to the model, Venkatesh and Davis (2000) suggested that subjective norm has a significant effect on behavioral intention, both directly and indirectly via its impact on perceived usefulness. Once a superior or peer suggests that a particular system might be useful, a person may consider that it is actually useful, and get the idea of using it (Taylor and Todd, 1995; Chan and Lu, 2004). Moreover, empirical evidence about the relationship between subjective norm and credit card's adoption can be found in many studies (Hayhoe et al., 1999; Hilgert and Hogarth, 2003; Norvilitis et al., 2006; Ismail et al., 2011). In Hayhoe et al. (1999), consumers are irresistible to observe and evaluate the benefits of credit cards and feel uncomfortable without them when their familiars use them every time and talk about them everywhere. As a result, those who do not own any credit cards will quickly seek for one to get along well with the community (Hayhoe et. al, 1999). Hilgert and Hogarth (2003), Norvilitis et al. (2006) determined that parents, schools, peers and the media are all part of a young person's learning and socialization from birth 
to adulthood. Ismail et al. (2011) mentioned that family influence has a significant impact on customers' decision to use credit cards. Additionally, media which is designed specifically to reach a large audience or viewers has contributed to improve consumers' awareness of credit cards (Ismail et al., 2011). Therefore, the following hypotheses are developed:

H2: Subjective norm positively affect the intention to use credit cards.

H3: Subjective norm positively affect the perceived usefulness of credit cards.

Customers' perceived behavioral control and their intention to use credit cards

Ajzen (1991, 2002) defined perceived behavioral control as an individual's perceived ease or difficulty in performing a particular behavior. It is assumed that perceived behavioral control is determined by the total set of accessible control beliefs. Therefore, perceived behavioral control can substitute for perceived ease of use in studies of technology acceptance (Ajzen, 2002), where perceived ease of use is an antecedent of not only intended behavior, but also perceived usefulness (Davis et al., 1989; Lu et al., 2003; Chan and Lu, 2004; Amin, 2007; Tu et al., 2011; Pham et al., 2013). These studies agreed that getting customers to access and use technology easily may change their perception of its performance, encourages them to accept and use it. Empirical evidence has been proved about the effects of perceived behavioral control on credit card's adoption. Barker and Sekerkaya (1992) stated that ease of payment was the main reason for using credit cards. Customers choose credit cards thanks to easy acceptability procedure of credit cards at retail outlets (Alhassan and Yakubu, 2007; Erdem (2008), Sudhagar, 2012). Mohammed (2001) assumed that the acceptance by a large number of different types of establishment affects the intention to use credit cards. Arbote and Busacca (2009) noted that the availability of the $24 / 7$ services is a vital element of credit card business. Social acceptance of credit card payments plays an important role in customers' decision of using credit cards instead cash to buy things (Kaynak and Harcar, 2001). Lydia et al. (2008) also mentioned that lack of understanding or minimum information might reduce the adoption of credit cards. Accordingly, this research proposes the following hypotheses:

H4: Perceived behavioral control has positive impact on intention to use credit cards.

H5: Perceived behavioral control has positive impact on perceived usefulness of credit cards.

Based upon the discussion in the previous section, the following theoretical model is developed from the TAM model (Figure 1).

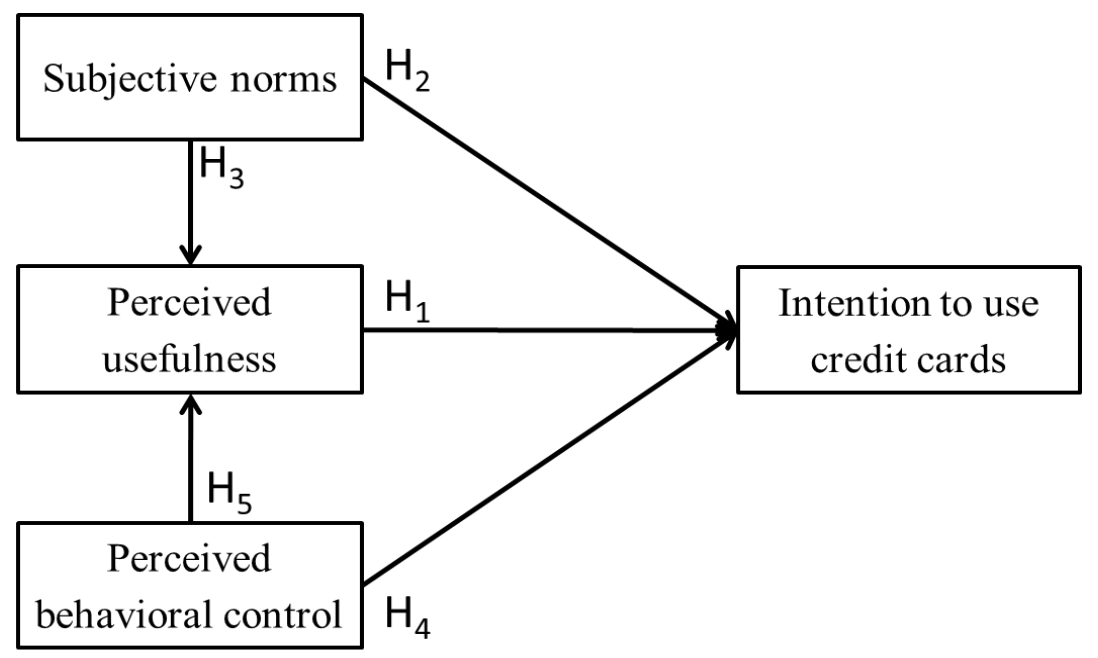

Figure 1. Proposed research model 


\section{Methodology and Data Collection}

This research conducted an online survey of customers in Ho Chi Minh City, who are bank account payers, thus highly potential for credit card application and use. Moreover, these customers also have experienced in banking services, especially in using bankcards for paying their daily expenses, and may easily accept an invitation for new credit card. The 22-item questionnaire focused on four components corresponding to the proposed research model. They are the intention to use credit cards (4 items), subjective norm (5 items), perceived usefulness (7 items), and perceived behavioral control (6 items). This study used 5-point Likert scale from 1-completely disagrees to 5completely agree (see Table I).

\section{Table 1}

4 factors with 22 measurements in proposed research model

\begin{tabular}{|c|c|c|}
\hline Code & Meaning & Reference \\
\hline PU1 & Purchase without carrying cash & $\begin{array}{l}\text { Barker and Sekerkaya (1992), Ahmed et al. } \\
\text { (2009), Thomas et al. (2010) }\end{array}$ \\
\hline PU2 & Buy first and repay later & Lee and Kwon (2002), Okan (2007) \\
\hline PU3 & Pay the bill & Hsu and Chiu (2004), Luarn and Lin (2005) \\
\hline PU4 & Access to cash easily if needed & $\begin{array}{l}\text { Roberts and Jones (2001), Norum (2008), Thomas } \\
\text { et al. (2010) }\end{array}$ \\
\hline PU5 & Promotions from popular branches & Lydia et al. (2008), Pudaruth et al.(2013) \\
\hline PU6 & Modern banking services & $\begin{array}{l}\text { Okan (2007), Pudaruth et al.(2013), Koparal } \\
(2014)\end{array}$ \\
\hline PU7 & Signal of identification & Ahmed et al. (2009), Koparal (2014) \\
\hline PBC1 & Simple registration & Hayhoe et al. (1999) \\
\hline $\mathrm{PBC} 2$ & Use credit card easily & Barker and Sekerkaya (1992), Ahmed et al. (2009) \\
\hline PBC3 & Learn to use easily & Erdem (2008) \\
\hline PBC4 & Payment everywhere and every time & $\begin{array}{l}\text { Kaynak and Harcar (2001), Alhassan and Yakubu } \\
\text { (2007) }\end{array}$ \\
\hline PBC5 & Transactions are performed in few seconds & Chan (1997), Pudaruth et al.(2013) \\
\hline PBC6 & Comfort and confidence & Lydia et al. (2008), Sudhagar (2012) \\
\hline NS1 & Family & $\begin{array}{l}\text { Palmer et al. (2001), Hilgert and Hogarth (2003), } \\
\text { Ismail et al. (2011) }\end{array}$ \\
\hline NS2 & Friends & Kaynak and Harcar (2001), Erdem (2008) \\
\hline NS3 & Co-workers & Palmer et al. (2001), Okan (2007) \\
\hline NS4 & Bankers & Hayhoe et al. (1999) \\
\hline NS5 & Multimedia & Kaynak and Harcar (2001), Ismail et al. (2011) \\
\hline IU1 & Desire to use & Davis et al. (1989) \\
\hline IU2 & Use as soon as possible & Davis et al. (1989) \\
\hline IU3 & Use usually in the future & Davis et al. (1989) \\
\hline IU4 & Encourage others to use & Davis et al. (1989) \\
\hline
\end{tabular}


The survey was conducted by using 463 respondents selected through convenient sampling, of which 426 answer sheets were eligible for analysis. With 22 observed variables, the required sample size is from 66 to 132 (Cattell, 1978). The data from 426 respondents are therefore compatible to this requirement.

Based on collected data, both exploratory factor analysis and confirmatory factor analysis are conducted to select and arrange the significant variables to particular factors. Finally, structural equation modeling is used for building the model of determinants of the intention to use credit cards.

\section{Findings}

\section{Descriptive statistics and Mean comparative analysis}

The descriptive statistics of survey data show that male, single or unmarried, and intellectual labor respondents have higher intention to use credit cards than female, married, and manual labor respondents, respectively. Moreover, 283 customers in golden age are more likely to accept credit cards than younger or older respondents. The respondents' regular income is relatively high and higher earning people have more desire to use credit cards. Finally, respondents with college or university degrees are more likely to adopt credit cards than those with lower or higher education (see Table II).

\section{Table 2}

Descriptive statistics and Mean comparative analysis

\begin{tabular}{|c|c|c|c|c|c|}
\hline Controlled variable & Frequency & Percent & Mean & $\begin{array}{l}\text { Levene } \\
\text { test (*) }\end{array}$ & $\mathbf{T}$ test $(* *)$ \\
\hline \multicolumn{6}{|l|}{ Gender } \\
\hline Female & 150 & 35.2 & 2.782 & \multirow{2}{*}{.828} & \multirow{2}{*}{.000} \\
\hline Male & 276 & 64.8 & 3.336 & & \\
\hline \multicolumn{6}{|l|}{ Marital status } \\
\hline Single & 323 & 75.8 & 3.199 & \multirow{2}{*}{.821} & \multirow{2}{*}{.012} \\
\hline Married & 103 & 24.2 & 2.959 & & \\
\hline \multicolumn{6}{|l|}{ Occupation } \\
\hline Manual labor & 111 & 26.1 & 2.881 & \multirow{2}{*}{.508} & \multirow{2}{*}{.000} \\
\hline Intellectual labor & 315 & 73.9 & 3.233 & & \\
\hline Controlled variable & Frequency & Percent & Mean & $\begin{array}{l}\text { Levene } \\
\text { test }(*)\end{array}$ & $\begin{array}{c}\text { ANOVA } \\
(* * *)\end{array}$ \\
\hline \multicolumn{6}{|l|}{ Age } \\
\hline Under 25 & 40 & 9.4 & 2.650 & \multirow{3}{*}{.535} & \multirow{3}{*}{.000} \\
\hline From 25 to 49 & 283 & 66.4 & 3.276 & & \\
\hline Above 49 & 103 & 24.2 & 2.961 & & \\
\hline
\end{tabular}




\begin{tabular}{|c|c|c|c|c|c|}
\hline Controlled variable & Frequency & Percent & Mean & $\begin{array}{l}\text { Levene } \\
\text { test (*) }\end{array}$ & $\mathbf{T}$ test $(* *)$ \\
\hline \multicolumn{6}{|l|}{ Regular income (monthly) } \\
\hline Under 500 USD & 45 & 10.6 & 2.883 & \multirow{5}{*}{.019} & \multirow{5}{*}{.001} \\
\hline 500 USD - 900 USD & 219 & 51.4 & 3.049 & & \\
\hline 900 USD - 1,600 USD & 138 & 32.4 & 3.319 & & \\
\hline 1,600 USD - 2,600 USD & 24 & 5.6 & 3.438 & & \\
\hline Above $2,600 \mathrm{USD}$ & 0 & 0 & 0 & & \\
\hline \multicolumn{6}{|l|}{ Education } \\
\hline High school graduation & 42 & 9.9 & 2.256 & \multirow{4}{*}{.012} & \multirow{4}{*}{.000} \\
\hline College graduation & 141 & 33.1 & 3.317 & & \\
\hline University graduation & 168 & 39.4 & 3.421 & & \\
\hline Master graduation or higher & 75 & 17.6 & 2.677 & & \\
\hline
\end{tabular}

(*) Significant level of Levene test

(**) Significant level of T-test

(***) Significant level of One-way ANOVA

The data collected from 426 respondents may be divided two independent groups based on specific demographic factors such as gender, marital status and occupation. Different sample $\mathrm{T}$ tests are used to compare the means of intention to use credit cards between these two independent groups. The $\mathrm{T}$ test for equality of means shows that the means of these groups are different significantly. Thus, male, single, intellectual respondents are more likely to use credit cards than female, married, manual ones, respectively. Factors such as age, income, and education used to divide the participants into more than two groups are compatible with one way ANOVA to compare the means of intention to use credit cards between these groups. All three groups have different means of intention to use credit cards, and these differences are significant (see Table II). Thereby, based on descriptive statistics, independent samples $\mathrm{T}$ test and one way ANOVA test, male, single or unmarried, intellectual, middle age (25-49 years old), high earning, and middle well-educated respondents are more likely to accept credit cards than others.

\section{Exploratory Factor Analysis}

An exploratory factor analysis (EFA) extracted 4 factors from 22 observed variables, except PU7 (PU7 is eliminated from the analysis because its loading factor is less than $0.5)$. These extracted factors are suitable to the proposal model. The KMO coefficient is 0.881 with a statistical significance of 0.000 , indicates that the EFA of the independent components is appropriate. A total extracted variance of variables is $55.262 \%$, which explains $55.262 \%$ data variation. Observed variables in intention to use credit cards (IU) have high loading coefficients $(\geq 0.8)$ and its data variation is well explained $(\geq 73 \%)$. Therefore, the measurements were acceptable for confirmatory factor analysis. 


\section{Table 3}

Exploratory factor analysis

\begin{tabular}{|c|c|c|c|c|c|c|}
\hline \multirow[b]{2}{*}{ Constructs } & \multicolumn{2}{|c|}{ EFA } & \multicolumn{2}{|c|}{ Reliability } & \multicolumn{2}{|c|}{ CFA } \\
\hline & 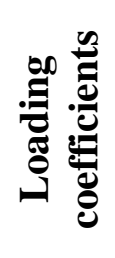 & 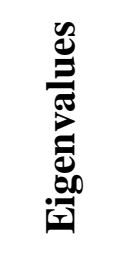 & 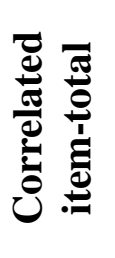 & 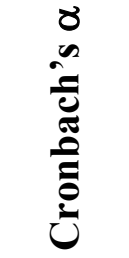 & 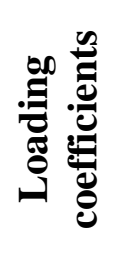 & 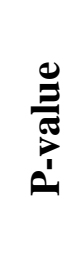 \\
\hline Perceived usefulness (PU) & & 5.910 & & 0.830 & & \\
\hline PU1 & .781 & & .626 & & .690 & $* * *$ \\
\hline PU2 & .773 & & .647 & & .730 & $* * *$ \\
\hline PU3 & .773 & & .624 & & .684 & $* * *$ \\
\hline PU4 & .626 & & .526 & & .585 & $* * *$ \\
\hline PU5 & .707 & & .591 & & .663 & $* * *$ \\
\hline PU6 & .705 & & .594 & & .671 & $* * *$ \\
\hline Perceived behavioral control (PBC) & & 1.748 & & 0.768 & & \\
\hline $\mathrm{PBC} 1$ & .656 & & .497 & & .581 & $* * *$ \\
\hline $\mathrm{PBC} 2$ & .721 & & .548 & & .624 & $* * *$ \\
\hline PBC3 & .608 & & .529 & & .633 & $* * *$ \\
\hline PBC4 & .627 & & .508 & & .607 & $* * *$ \\
\hline PBC5 & .670 & & .453 & & .525 & $* * *$ \\
\hline PBC6 & .732 & & .533 & & .611 & $* * *$ \\
\hline Subjective norm (SN) & & 1.584 & & 0.706 & & \\
\hline SN1 & .707 & & .429 & & .513 & $* * *$ \\
\hline SN2 & .675 & & .466 & & .559 & $* * *$ \\
\hline SN3 & .681 & & .499 & & .616 & $* * *$ \\
\hline SN4 & .637 & & .448 & & .575 & $* * *$ \\
\hline SN5 & .652 & & .469 & & .586 & $* * *$ \\
\hline Intention to use credit cards (IU) & & 2.930 & & 0.865 & & \\
\hline IUU1 & .851 & & .712 & & .862 & $* * *$ \\
\hline IU2 & .844 & & .696 & & .869 & $* * *$ \\
\hline IU3 & .869 & & .776 & & .669 & $* * *$ \\
\hline IU44 & .856 & & .758 & & .645 & $* * *$ \\
\hline
\end{tabular}

\section{Confirmatory Factor Analysis}

A confirmatory factor analysis (CFA) is applied for proposed model with 4 factors and 21 observed variables to examine the modeldata fit. Absolute indices, such as Chi-square,
Goodness-of-Fit Index (GFI), Comparative Fit Index (CFI), Tucker \& Lewis Index (TLI) and Root Mean Square Error of Approximation (RMSEA) are used to evaluate the proposed model. Empirical results are as follows - Chi- 
square $/ \mathrm{df}=1.862, \quad \mathrm{GFI}=0.927, \quad \mathrm{CFI}=0.948$, $\mathrm{TLI}=0.940$ and RMSEA $=0.045$. The results indicate that the suggested model is appropriate (McDonald and Ho, 2002). Next, the validity of convergence is achievable because all factor loadings are greater than 0.5 (Table III) and significant t-statistics (Gerbring and Anderson, 1988). Table III shows that the internal consistency reliability of measurements is accepted when overall reliability coefficient is greater than 0.6 and the values of corrected item-total correlation are greater than 0.3 for all observed variables
(Nunnally and Burnstein, 1994; Schumacker and Lomax, 2006). Moreover, the correlation coefficients between 4 constructs are significantly less than 1.0 (Table IV). Their observed variables' internships do not exist, then each factor is a distinct construct and discriminant validity is acceptable (Steenkamp and Trijp, 1991). Therefore, CFA results confirm that 21 observed variables are extracted into 4 constructs and the measurements are model-data fit, discriminant validity, unidimensionality, convergence validity and internal consistency reliability.

\section{Table 4}

The correlation coefficients between extracted constructs in CFA

\begin{tabular}{rclcccc}
\hline & Correlation & & Coefficients & S.E. & C.R. & P. \\
\hline PU & $<-->$ & PBC & .570 & .026 & 7.022 & $* * *$ \\
PU & $<-->$ & SN & .432 & .024 & 5.680 & $* * *$ \\
PBC & $<-->$ & SN & .463 & .022 & 5.697 & $* * *$ \\
PU & $<-->$ & IU & .437 & .042 & 6.311 & $* * *$ \\
SN & $<-->$ & IU & .503 & .041 & 6.323 & $* * *$ \\
PBC & $<-->$ & IU & .467 & .039 & 6.281 & $* * *$ \\
\hline
\end{tabular}

\section{Structural Equation Modeling}

A structural equation model (SEM) is conducted to test the proposed model with 2 independent constructs (subjective norm and perceived behavioral control) and 2 dependent constructs (perceived usefulness and intention to use credit card). Figure 2 shows the whole SEM for the proposed model. All indicators (Chi-square/df=2.140, GFI=0.917, CFI=0.930, $\mathrm{TLI}=0.920$ and $\mathrm{RMSEA}=0.052$ ) show that the proposed model is appropriate for data collected from the market (McDonald and Ho, 2002). The result of SEM is described in Table V. Whereby, perceived usefulness, subjective norm and perceived behavioral control accounted for 30 percent of the variance in intention to use credit cards with coefficients of $0.27,0.66$ and 0.49 , respectively. Moreover, subjective norm and perceived behavioral control are antecedents of perceived usefulness of credit card. Therefore, all hypotheses are accepted.

\section{Table 5}

Results of the structural equation model

\begin{tabular}{ccccccccc}
\hline Hypothesis & \multicolumn{2}{l}{ Relationship } & Estimate & S.E. & C.R. & P. & Result \\
\hline H1 & PU & $\rightarrow$ & IU & .267 & .114 & 2.332 & .020 & Accepted \\
H2 & SN & $\rightarrow$ & IU & .661 & .129 & 5.111 & $* * *$ & Accepted \\
H3 & SN & $\rightarrow$ & PU & .310 & .072 & 4.321 & $* * *$ & Accepted \\
H4 & PBC & $\rightarrow$ & IU & .487 & .129 & 3.788 & $* * *$ & Accepted \\
H5 & PBC & $\rightarrow$ & PU & .558 & .078 & 7.195 & $* * *$ & Accepted \\
\hline
\end{tabular}




\section{Discussion}

Few local authors have paid attention to the issue of credit cards in Vietnam. Some studies on credit card are primarily concerned about credit card service's quality (Nguyễn, 2014), credit cardholders' satisfaction (Nguyễn and Huỳnh, 2013) or delinquency of credit card (Nguyễn and Trịnh, 2013). Meanwhile, consumers' acceptance or intention to use credit cards has not been mentioned in prior studies on credit cards in Vietnam. This study aims to fill this gap by applying TAM and TPB as theoretical frameworks with data collected from nationwide survey.

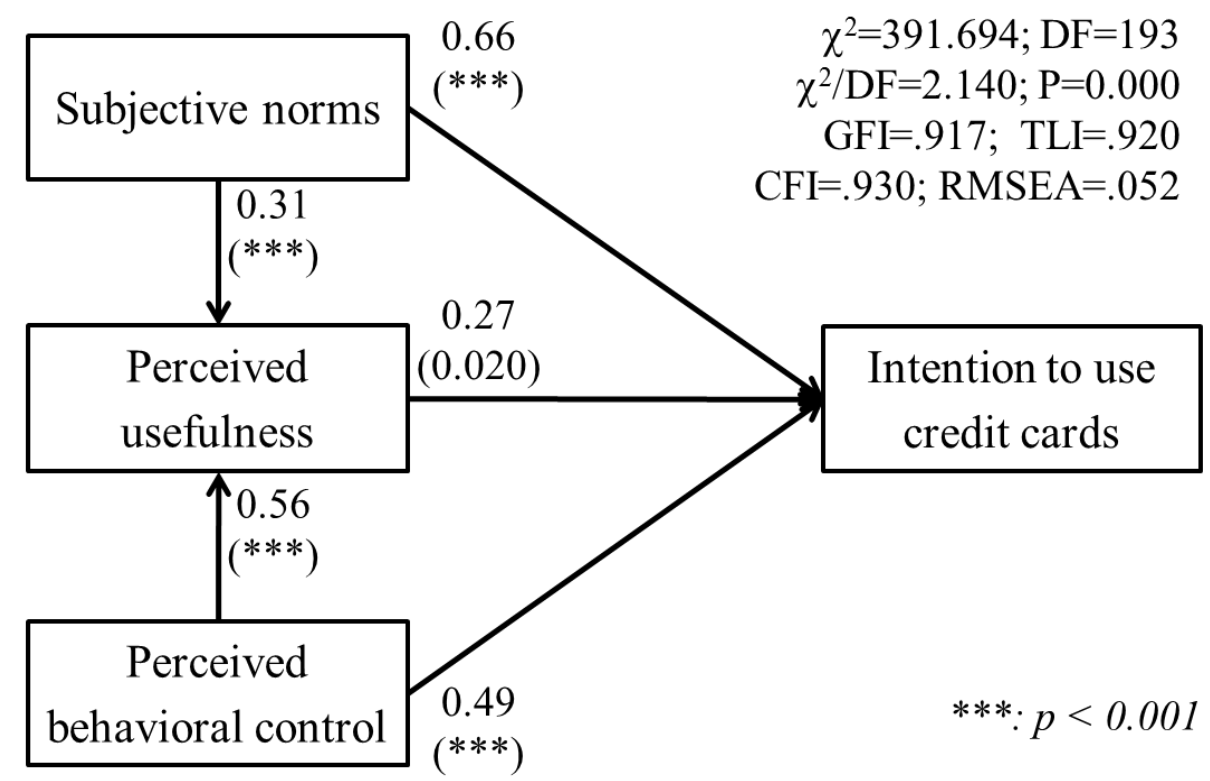

Figure 2. Proposed research model and the results of SEM

Consumers are rational, they tend to do things that they feel to gain benefits (Ajzen and Fishbein, 1980; Davis et al., 1989; Ajzen, 1991). SEM results show that consumers' perceived usefulness significantly affects their intention to use credit cards $(\beta=0.27$; $\mathrm{p}=0.000$ ). This result is consistent with prior worldwide studies (Barker and Sekerkaya, 1992; Kaynak and Harcar, 2001; Roberts and Jones, 2001; Lee and Kwon, 2002; Hsu and Chiu, 2004; Luarn and Lin, 2005; Alhassan and Yakubu, 2007; Norum, 2008; Thomas et al., 2010; Sudhagar, 2012; Pudaruth et al., 2013) when customers adopt credit card as a useful tool for both payment and credit purpose. However, unlike the findings of Ahmed et al.'s (2009) or Koparal's (2014) studies, Vietnamese consumers do not assume that credit card contributes to personal value. Thus, signal of identification is eliminated from perceived usefulness construct of credit cards.

Next, the impact of subjective norm is found in both behavioral intention $(\beta=0.66$; $p=0.000)$ and perceived usefulness $(\beta=0.31$; $\mathrm{p}=0.000$ ) of credit card. This finding is consistent with that of studies by Lea et al. (1993), Hayhoe et al. (1999), Kaynak and Harcar (2001), Norvilitis et al. (2006), Allen et al. (2007) in that consumers tend to accept credit cards if their relatives use and enjoy it. Meanwhile, one may consider that credit card is useful when his relatives think or suggest that (Taylor and Todd, 1995; Venkatesh and Davis, 2000; Chan and Lu, 2004). Thereby, family, friends, co-workers and the media play more and more frequently in their lives and have increasing influences on their own (Venkatesh and Davis, 2000; Hilger and Hogarth, 2003; Ismail et al., 2011).

Finally, credit cards are primarily used on electronic media, requiring cardholders to 
know and follow strictly user's instruction. Consumers tend to accept credit card when it is easy to access, simple to manipulate and easy to use right from the first transaction. This is reflected in Table $\mathrm{V}$ where perceived behavior control has positive effect $((\beta=0.49$; $\mathrm{p}=0.000)$ on one's decision to use or not to use credit card. This result is consistent with that of previous studies (Barker and Sekerkaya, 1992; Alhassan and Yakubu, 2007; Lydia et al., 2008; Arbote and Busacca, 2009; Sudhagar, 2012). Additionally, perceived behavioral control is also associated with perceived usefulness of credit card $(\beta=0.56 ; p=0.000)$, this is consistent with prior research which proved that perceived behavioral control significantly affects perceived usefulness on adoption of new technology (Davis et al., 1989; Ajzen, 1991, 2002; Lu et al., 2003), electronic services (Chan and Lu, 2004; Pham et al., 2013) as well as payment card (Amin, 2007; Tu et al., 2011). All together, the intention to use credit cards of Vietnamese consumers is affected by perceived usefulness, subjective norm and perceived behavioral control. Of these three constructs, subjective norm has the most impact on intended behavior while perceived usefulness least influenced on intention to use credit card.

\section{Conclusion}

In recent years, Vietnamese banks have gained some achievements in credit card business. However, these achievements do not correspond to the potential of the market. Only over 3 million credit cards (out of more than 80 million bankcards) were issued with total sales of about 2 billion dollars (out of total sales of about 65 billion dollars) in 2014. Therefore, Vietnamese banks are constantly deploying new products and services in credit card service to improve the performance in both issuing and acquiring operations. However, banks do not pay proper attention to the customers' perception of the credit cards as a combination of payment instrument and individual consumer credit.
Considering that many customers have a negative attitude towards credit cards, and reject the issuing offers, this study proposes a combination of TAM and TPB and applies SEM to determine the factors affecting the intention to use credit cards among Vietnamese adults. The results reveal that perceived usefulness, perceived behavioral control and subjective norm have a positive effect on intention to use credit cards. In other words, when credit cards are more efficient, easier to access and manipulate; consumers may feel more motivated to use credit cards. Customers will also appreciate their usefulness and this will, in turn, help improve credit card's adoption. Additionally, positive impact of subjective norm on behavioral intention means that consumers are easily influenced by superiors, peers and media.

Although this study provided substantive explanations for customers' acceptance of credit cards, it still has several limitations. It only considered the intention to use credit cards based on the effects of subjective norm, perceived usefulness and perceived behavioral control driven from TAM and its versions. However, customers only accept to use credit cards when they wants to use these instruments for their future's need. Benefits and costs are carefully taken into account when customers actually use credit cards. In addition, this study has not determined the role of customers' demographic characteristics in their decision to use or not to use credit cards. Thereby, future studies should address these shortcomings.

This research can be beneficial to Vietnamese banks enacting policies to encourage customers to register and use credit cards for paying goods and services. Banks may focus on highly potential customers who are male, single, intellectual, middle age, well-educated and high income based on their high intention to use credit cards. Moreover, changing consumers' perception toward credit cards should be carried out seriously and continuously. Customers should be provided 
with adequate information about credit cards including utilities, functionalities, using fees, arisen problems and solutions to such problems. This information gives customers a more comprehensive view of credit cards, a special product of modern banking services. Once customers are fully aware of credit cards and their benefits, they will be ready to accept the offers made by credit card issuers and encourage others to use credit cards

\section{References}

Ahmed A., Ayesha A., Hamid M. (2009). Consumer Perception and Attitude towards Credit Card Usage: A Study of Pakistani Consumers. Journal of Comparative International Management, 12(1), 47-57.

Ajzen I. (1991). The theory of planned behavior, Organizational Behavior and Human Decision Process, 50(2), 179-211.

Ajzen I. (2002). Perceived behavioral control, self-efficacy, locus of control, and the theory of planned behavior. Journal of Applied Social Psychology, 32, 665-683.

Ajzen I. (2008). Consumer attitudes and behavior, Handbook of Consumer Psychology, New York: Lawrence Erlbaum Associates, 525-548.

Ajzen I., Fishbein M. (1980). Understanding attitudes and predicting social behavior. Englewood Cliffs, NJ: Prentice-Hall.

Alhassan G., Yakubu A.U. (2007). Credit card ownership and usage behavior in Saudi Arabia: The impact of demographics and attitudes towards debt. Financial Services Marketing, 12(3), 219-234.

Amin H. (2007). An analysis of mobile credit card usage intentions. Information Management \& Computer Security, 15(4), 260-269.

Arbore A., Busacca B. (2009). Customer satisfaction and dissatisfaction in retail banking: Exploring the asymmetric impact of attribute performances. Journal of Retailing and Consumer Services, 16, 271-280.

Barker T., Sekerkaya A. (1992). Globalization of credit card usage: the case of a developing economy. International Journal of Bank Marketing, 10(6), 27-31.

Cattell R. B. (1978). Matched determiners vs. factor invariance: A reply to Korth. Multivariate Behavioral Research, 13, 431-448.

Chan R.Y. (1997). Demographic and attitudinal differences between active and inactive credit cardholders - the case of Hong Kong. International Journal of Bank Marketing, 15(4), 117-125.

Chan S.C., Lu M.T (2004). Understanding Internet Banking Adoption and Use Behavior: A Hong Kong Perspective. Journal of Global Information Management, 12(3), 21-43.

Chau P., Hu P. (2002). Examining a Model of Information Technology Acceptance by Individual Professionals: An Exploratory Study. Journal of Management Information Systems, 18, 191-229.

Davis F. D. (1989). Perceived usefulness, perceived ease of use, and user acceptance of information technology. MIS Quarterly, 13(3), 319-340.

Davis F.D, Bagozzi R.P., Warshaw P.R. (1989). User acceptance of computer technology: A comparison of two theoretical models. Management Sciences, 35(8), 982-1003.

Erdem C. (2008). Factors Affecting the Probability of Credit Card Default and the Intention of Card Use in Turkey. International Research Journal of Finance and Economics, 18, 159-171.

Gerbing D., Anderson J.C. (1988). An updated paradigm for scale development incorporating unidimensionality and its assessment. Journal of Marketing Research, 25, 186-192.

Hayhoe C.R., Leach L.J. (1999). Discriminating the number of credit cards held by college students using credit and money attitudes. Journal of Economics Psychology, 20, 643-656. 
Hilgert M.A., Hogarth G.M. (2003). Household financial management: The connection between knowledge and behavior. Federal Reserve Bulletin, 89(7), 309-322.

Hsu M.H., Chiu C.M. (2004). Internet self-efficacy and electronic service acceptance. Decision Support Systems, 38, 369-381.

Ismail S., Serguieva A., Singh S. (2011). Integrative model to students' attitude to educational loan repayment: A structural modeling approach. Journal of International Education in Business, 4(2), 125-135.

Kaynak E., Harcar T. (2001). Consumers' Attitudes and Intentions towards Credit Card Usage in an Advanced Developing Country. Journal of Financial Services Marketing, 6(1), 24-39.

Koparal, C., Calik N. (2014). Bank credit card usage behavior of individuals; are credit cards considered as status symbols or are they really threats to consumers' budgets? A field study from Eskisehir, Turkey. International Journal of Social Sciences, 3(4), 75-97.

Lee J., Kwon K.N. (2002). Consumers' use of credit cards: Store credit card usage as an alternative payment and financing medium. The Journal of Consumer Affairs, 36(2), 239-262.

Lee S.M., Cata T. (2005). Critical success factors of Web-based e-service: The case of e-insurance. International Journal of E-Business Research, 1(3), 21-40.

Lin C., Nguyen C.H. (2011). Exploring e-payment adoption in Vietnam and Taiwan. The journal of Computer information systems, 51(4), 41-52.

Lu J., Chang Li., James Y. (2003). Technology acceptance model for wireless Internet. Internet Research, 13(3), 206-216.

Luarn P., Lin H. (2005). Toward an understanding of the behavioural intention to use mobile banking. Computers in Human Behavior, 21(6), 873-891.

Lydia L.G., Ramin C.M., Koh H.C. (2008). Singapore credit cardholders: ownership usage patterns and perceptions. Journal of Services Marketing, 22(4), 267-279.

McDonald R.P., Ho M-H. R. (2002). Principles and practice in reporting structural equation analyses. Psychological Methods, 7, 64-82.

Meier A., Stormer H. (2009). eBusiness \& eCommerce: Managing the Digital value chain. Springer-Verlag Berlin Heidelberg.

Nguyễn Minh Hà, Trịnh Hoàng Nam (2013). Các nhân tố tác động đến rủi ro tín dụng trong hoạt động kinh doanh thẻ tín dụng tại Việt Nam. Banking technology review, 88, 3-9.

Nguyễn Quang Vinh, Huỳnh Thị Phương Lan (2014). Mối liên hệ giữa chi phí chuyển đổi, sự hài lòng và lòng trung thành của khách hàng sử dụng dịch vụ ngân hàng. Tạp chí Phát triển Khoa học và Công nghệ, 16, 77-85.

Nguyễn Thị Hằng (2014). Mô hình đánh giá chất lượng dịch vụ thẻ tín dụng của ngân hàng thương mại Việt Nam. Tạp chí Khoa học và Công nghệ, 118, 75-80.

Norum, P. S. (2008). The role of time preference and credit card usage in compulsive buying behaviour. International Journal of Consumer Studies, 32, 269-275.

Norvilitis J., Merwin M., Osberg T., Roehling P., Young P., Kamas M. (2006). Personality factors, money attitudes, financial knowledge, and credit-card debt in college students. Journal of Applied Social Psychology, 36, 13951413.

Nunnally J.C., Burnstein I.H. (1994). Psychometric theory (3e). McGraw-Hill, New York.

Okan V.S. (2007). Motivating factors of Credit card usage and ownership: Evidence from Northern Cyprus. Investment Management and Financial Innovations, 4(4), 133-143.

Palmer T.S., Pinto M.B., Parente D.H. (2001). College Students' Credit Card Debt and the Role of Parental Involvement: Implications for Public Policy. Journal of Public Policy \& Marketing, 20, 105-113. 
Park J., Lee D., Ahn J. (2004). Risk-Focused e-Commerce Adoption Model-A Cross Country Study. Journal of Global Information Technology Management, 7(2), 6-30.

Payam H., Hamid R.K. (2012). The mediating role of the dimensions of the perceived risk in the effect of customers' awareness on the adoption of Internet banking in Iran. Electron Commer Research, 12, 151-175.

Peterson R. A. (1994). A Meta-Analysis of Cronbach's Coefficient Alpha. Journal of Consumer Research, 21(2), 381-391.

Pham L., Cao Y.N., Nguyen D.T., Tran T.P. (2013). Structural models for E-Banking Adoption in Vietnam. International journal of enterprise information system, 9(1), 31-48.

Pudaruth S., Juwaheer T.D., Madoo V. (2013). Mapping the Hidden Constructs towards the Adoption of Plastic Cards in Mauritius. International Journal of Advanced Research, 1(4), 340-355.

Roberts J.A, Jones E. (2001). Money attitudes, credit card use, and compulsive buying among American college students. The Journal of Consumer Affairs, 35(2), 213-240.

Schumacker R.E., Lomax R.G. (2010). A beginner's guide to structural equation modeling (3rd). New York: Routledge.

Steenkamp J.E.M., Van Trijp H.C.M. (1991). The use of LISREL in validating marketing constructs. International Journal of Research in Maketing, 8, 283-299. North-Holland: Elsevier Science Publishers B.V.

Sudhagar S. (2012). A Study on Perception and Awareness on Credit Cards among Bank Customers in Krishnagiri District. Journal of Business and Management, 2(3), 14-23.

Taylor S., Todd P.A. (1995). Understanding information technology usage: A test of competing models, Information systems research, 6(2), 144-176.

Teoh W.M., Chong S.C., Yong S.M. (2013). Exploring the factors influencing credit card spending behavior among Malaysians. International Journal of Bank, 31(6), 481-500.

Thomas F., Maloles C., Swoboda B. (2010). Debit and credit card usage and satisfaction: Who uses which and whyevidence from Austria, International Journal of Bank Marketing, 28(2), 150-165.

Tu T.T., Chang H.H., Chiu Y.H. (2011). Investigation of the factors influencing the acceptance of electronic cash stored-value cards, African Journal of Business Management, 5(1), 108-120.

Venkatesh V., Davis F.D. (2000). A Theoretical Extension of the Technology Acceptance Model: Four Longitudinal Field Studies. Management Science, 46(2), 186-204.

Yayar R., Karaca S.S. (2012). Identifying the factors affecting the consumer credit card ownership: Empirical evidence from Turkey. Journal of Applied economic sciences, 7(20), 195-204.

Zhao A.L., Lloyd S.H., Ward P., Goode M.M. (2008). Perceived risk and Chinese consumers' internet banking services adoption. International Journal of Bank Marketing, 26(7), 505-525. 